\title{
Cloning cDNAs for Genes Preferentially Expressed during Fruit Growth in Cucumber
}

\author{
Takuro Suyama, Kunio Yamada, Hitoshi Mori, Kiyotoshi Takeno, ${ }^{1}$ and Shohei Yamaki \\ Graduate School of Bioagricultural Sciences, Nagoya University, Nagoya 464-8601, Japan
}

\begin{abstract}
AdDitional INDEX WORDs. naphthaleneacetic acid, parthenocarpy, pollination, subtraction hybridization
Abstract. A cDNA library was constructed from poly(A)+RNA extracted from pollinated fruit of 'PMR-142' cucumber (Cucumis sativus $\mathrm{L}$.). Subtraction hybridization was made between the cDNAs and poly $(A)^{+} \mathrm{RNA}$ from unpollinated fruit to isolate cDNA clones that corresponded to the genes preferentially expressed in the pollinated fruit. We isolated three cDNAs, which were 756, 826, and 998 nucleotides long and designated Csf1, Csf2, and Csf3, respectively. When fruit growth was triggered by pollination, auxin treatment and natural parthenocarpy, Csf 2 was always expressed. Time course of expression of the Csf 2 gene was nearly parallel to that of the fruit growth. Nucleotide sequences of the Csf cDNAs were fully determined. Homology of the deduced amino acid sequence for Csf1 showed $75 \%$ identity with a pea extensin. Only $37 \%, 33 \%$, and $26 \%$ homology was found between Csf2 and bell pepper CaSn-2, tobacco FB7-4, and opium poppy gMLP15, respectively. The Csf3 sequence showed $68 \%$ identity with the large subunit of $60 \mathrm{~S}$ ribosomal protein L3 of Arabidopsis thaliana.
\end{abstract}

Physiological studies have shown that fruit growth is regulated by plant hormones and sugar metabolism (Hedden and Hoad, 1985). Genes whose expression is positively correlated with fruit growth have been reported from several species including tomato (Lycopersicon esculentum Mill.) (Pear et al., 1989; Salts et al., 1991; Tieman and Handa, 1996), peach (Prunus persica Batsch.) (Callahan et al., 1993), kiwifruit [Actinidia deliciosa (A. Chev.) C.F. Liang et A.R. Ferguson var. deliciosa] (Ledger and Gardner, 1994), and apple (Malus pumila Miller var. domestica Schneid.) (Dong et al., 1997). However, roles of these genes in the regulation of fruit growth are still unknown.

In addition to triggering fruit growth, pollination induces ethylene synthesis and many other biochemical responses (Wang et al., 1996). Therefore, some of the genes expressed after pollination may not be directly related to fruit growth. Our strategy to isolate the specific genes regulating fruit growth was to identify genes which are activated in fruit whose growth was triggered by each of several different factors. Unpollinated cucumber flowers are responsive to auxin for induction of parthenocarpic fruit growth (Takeno et al., 1992). The cultivar ('PMR-142') used in the present study, also has the potential to set fruit parthenocarpically from flowers formed at higher nodes (Takeno and Ise, 1992). Therefore, fruit growth in this cucumber genotype can be induced by three different factors, pollination, auxin treatment and natural parthenocarpic potential. In the present work, we used subtractive hybridization to clone cDNAs expressed during fruit growth of cucumber.

\section{Materials and Methods}

Plant materials. 'PMR-142' cucumber was used for all experiments. The seeds were planted in unglazed pots $(21 \mathrm{~cm}$ in diameter) filled with soil, and the plants were grown in a glasshouse under natural conditions from May to July. The female flowers formed on the 14th and lower nodes and those on the 26th

Received for publication 18 Mar. 1998. Accepted for publication 29 Oct. 1998. The nucleotide sequences reported in this paper have been submitted to DDBJ, EMBL and GeneBank nucleotide sequence databases under the accession numbers $\mathrm{AB} 008846$ to $\mathrm{AB} 008848$. The cost of publishing this paper was defrayed in part by the payment of page charges. Under postal regulations, this paper therefore must be hereby marked advertisement solely to indicate this fact.

${ }^{1}$ To whom reprints requests should be addressed. and higher nodes were used. The former has a low potential to set parthenocarpic fruit and the latter has a high potential to do so (Takeno and Ise, 1992).

To induce male flowers in this gynoecious cultivar, a $50 \%$ acetone solution containing $2.9 \times 10^{-4} \mathrm{M}$ gibberellin $\mathrm{A}_{3}$ and an aqueous solution of $1.6 \times 10^{-3} \mathrm{M}$ aminoethoxyvinyl glycine were sprayed on leaves once a week. Female flowers were covered with paper bags the day before anthesis, and were either artificially pollinated the next morning or left unpollinated. Ten microliters of a $50 \%$ acetone solution containing $5.4 \times 10^{-3} \mathrm{M}$ naphthaleneacetic acid (NAA) (Sigma Chemical Co., St. Louis) was applied once to ovaries of some unpollinated flowers on the day of anthesis.

Fruit were harvested at $0,1,2,3,5$, or $7 \mathrm{~d}$ after anthesis depending on the experiment. After measuring length and fresh weight, the fruit were frozen in liquid nitrogen. The fruit length and fresh weight were shown as means of 5 to 37 fruit with SE. Roots, stem tips including young leaf primordia, mature leaves at nodes 6 to 10 , and stem segments between nodes 6 and 10 were also harvested.

ISOLATION OF POLY(A $)^{+}$RNA. To extract total RNA, plant material $(10 \mathrm{~g})$ was homogenized in $50 \mathrm{~mL}$ water-saturated phenol and 50 $\mathrm{mL} \mathrm{0.2} \mathrm{м} \mathrm{Tris-HCl} \mathrm{buffer} \mathrm{(} \mathrm{pH} 9.0$ ) containing $0.2 \mathrm{M} \mathrm{LiCl}, 5 \mathrm{~mm}$ ethylenediaminetetraacetic acid (EDTA), $1 \%$ sodium dodecylsulfate (SDS) and 1\% 2-mercaptoethanol. The homogenate was centrifuged at $5,000 g_{\mathrm{n}}$ for $5 \mathrm{~min}$ to collect the aqueous phase. The aqueous phase was added with an equal volume of chloroform, and the mixture was shaken vigorously and then centrifuged at 5,000 $g_{\mathrm{n}}$ for $5 \mathrm{~min}$. The aqueous phase $(\approx 55 \mathrm{~mL})$ was combined with $\mathrm{NaCl}$ and cetyltrimethylammonium bromide (CTAB) to a final concentration of $0.7 \mathrm{~m}$ and $1.0 \%$, respectively and an equal volume of chloroform. The mixture was shaken vigorously, then centrifuged at 5,000 $g_{\mathrm{n}}$ for $5 \mathrm{~min}$. An equal volume of 2-propanol and 1/ 300 -volume of acetic acid were added to the aqueous phase, the mixture was incubated at room temperature for $1 \mathrm{~h}$, and the precipitate was collected at $10,000 g_{\mathrm{n}}$ for $10 \mathrm{~min}$. The precipitate was dissolved in $10 \mathrm{~mm}$ Tris- $\mathrm{HCl}$ buffer $(\mathrm{pH} 8.0)$ containing $1 \mathrm{~mm}$ EDTA (TE) and added with $\mathrm{LiCl}$ to a final concentration of $2 \mathrm{M}$. The mixture was placed on ice for $1 \mathrm{~h}$, then centrifuged at 10,000 $g_{\mathrm{n}}$ for $5 \mathrm{~min}$. The precipitate was washed with ethanol and dissolved in TE to be used as total RNA. Poly(A)+RNA was isolated from the total RNA by oligo(dT)-cellulose, Type 7 (Pharmacia Biotech, Uppsala, Sweden) chromatography. 
A
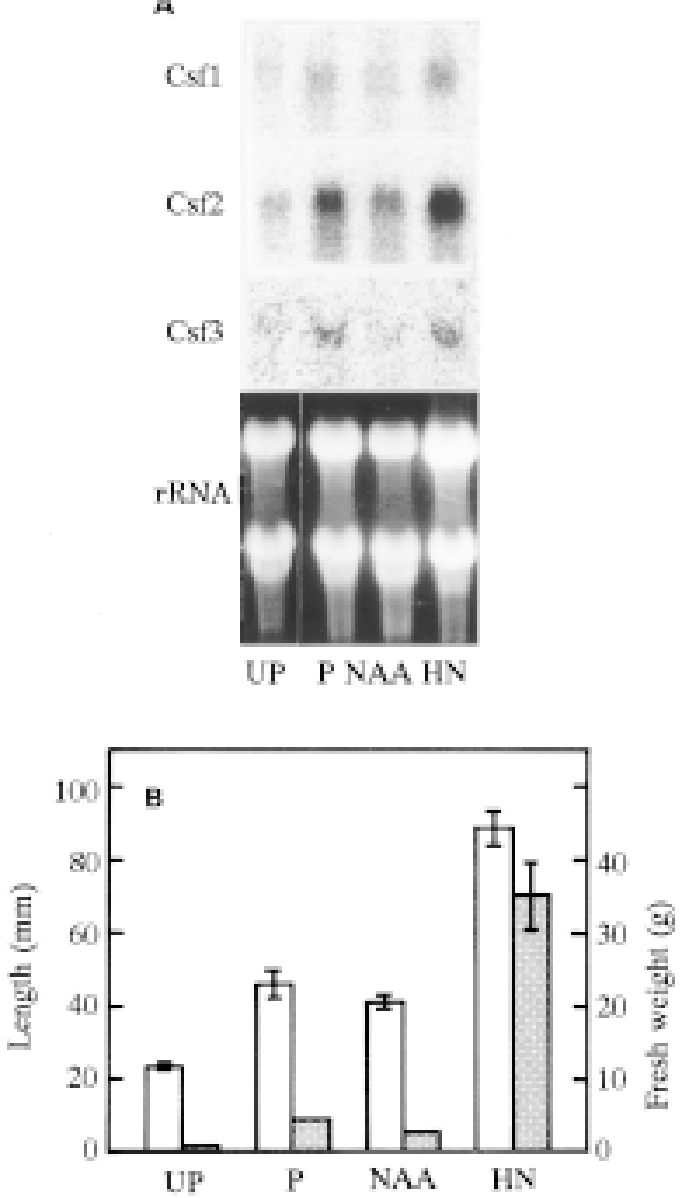

Fig. 1. Correlation of expression of Csf genes with fruit growth in 'PMR-142' cucumbers $3 \mathrm{~d}$ after anthesis determined by northern blot analysis. (A) Total RNAs extracted from pollinated (P), unpollinated (UP) fruit, unpollinated fruit treated with NAA(NAA), and unpollinated fruit on the 26th and higher nodes (HN) were used. Ten micrograms of RNA per lane was loaded and ethidium bromide staining of rRNA was used as a loading conrtrol. (B) Length (open columns) and fresh weight (shaded columns) of the fruit. Values are means $\pm \mathrm{SE}$.

SubTRACTION HYBRIDIZation. The cDNA Synthesis Kit (Amersham Japan, Tokyo) was used to synthesize cDNA from poly(A)+RNA (5 $\mu \mathrm{g}$ obtained from pollinated fruit $3 \mathrm{~d}$ after anthesis. Poly(A) ${ }^{+}$RNA (10 $\mu \mathrm{g}$ from unpollinated fruit $3 \mathrm{~d}$ after anthesis was hybridized with the first-strand cDNAs and the common messages were cross-linked by the method of Hampson et al. (1992). The single-stranded subtraction product cDNAs were labeled with $\left[{ }^{32} \mathrm{P}\right]$ deoxycytidine 5 '-triphosphate (dCTP) using Multiprime DNA Labeling System (Amersham Japan).

CONSTRUCTION OF A CDNA LIBRARY AND COLONY HYBRIDIZATION. A cDNA library was constructed with poly $(\mathrm{A})+\mathrm{RNA}$ isolated from 3-d-old pollinated fruit in the vector pBluescript SK(-) (Strategene, La Jolla, Calif.) according to the method of Mori et al. (1991). About 3,000 colonies of transformed Escherichia coli DH5 $\alpha$ were blotted onto a nitrocellulose filter, and probed with ${ }^{32} \mathrm{P}$-labeled subtraction product cDNAs. Hybridization was carried out in a mixture of $0.9 \mathrm{M} \mathrm{NaCl}, 60 \mathrm{~mm} \mathrm{NaH}_{2} \mathrm{PO}_{4}$ and $7.5 \mathrm{~mm}$ EDTA, pH 7.4 (6× SSPE), 50\% formamide, 5\% Irish Cream (R. and A. Bailey \& Co., Dublin, Ireland), $0.5 \%$ SDS and $100 \mu \mathrm{g} \cdot \mathrm{mL}^{-1}$ denatured salmon sperm DNA at $42{ }^{\circ} \mathrm{C}$ for $14 \mathrm{~h}$. The filter was washed twice with $2 \times \mathrm{SSPE}$ containing $0.1 \% \mathrm{SDS}$ at $65^{\circ} \mathrm{C}$ for 30

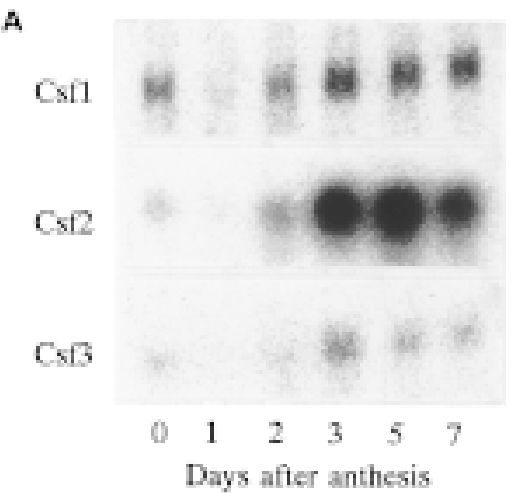

Days after anthesis

Fig. 3. Expression of Csf genes in roots $(\mathrm{R})$, stem between the 6 th node and 10th node $(\mathrm{S})$, mature leaves attached to the 6th to 10th nodes (L), stem tip including young leaf primordia (T), and 3-d-old pollinated fruit $(\mathrm{F})$ of 'PMR-142' cucumber.

min each. The hybridizing colonies were visualized by Imaging Plate BAS III (Fuji Film, Tokyo).

NORTHERN BLOT ANALYSIS. Total RNA $(10 \mu \mathrm{g}$ was subjected to electrophoresis on $1.0 \%$ agarose gels in the presence of $0.66 \mathrm{M}$ formaldehyde, and transferred by blotting to a Hybond- $\mathrm{N}^{+}$membrane (Amersham Japan). To demonstrate equal loading of samples, the agarose gels were stained with ethidium bromide to detect rRNA. The membrane was probed with [ $\left.{ }^{32} \mathrm{P}\right]$-labeled cDNAs. Hybridization was carried out at $42{ }^{\circ} \mathrm{C}$ overnight in the same manner as for the colony hybridization.

SEQuence of cDNa. The plasmids containing cDNA inserts were digested with $\mathrm{HincII}$ and $\mathrm{ClaI}$ and subcloned into pBluescript SK(-). Nucleotide sequences were determined using a DNAsequencer (LI-4000; LI-COR Inc., Lincoln, Neb.) and the TaKaRa Cycle-sequencing Kit with $\mathrm{IRD}_{41} \mathrm{~T} 3$ primer (LI-COR). Homology of each cDNA was determined by searching the GenomeNet Kyoto-Center NR-AA database.

\section{Results}

Cloning AND EXPRESSION OF THREE FRUIT-DERIVED CDNAS. Colony hybridization of the cDNA library for pollinated fruit with the subtraction product cDNAs provided 20 positive clones. These cDNAs are hereafter called Csf (Cucumis sativus fruit) cDNAs. When the Csf cDNAs were used to probe total RNA from unpollinated and pollinated fruit, three of the Csf clones detected more abundant mRNAs in the pollinated fruit than in the unpollinated ones (Fig. 1A, UP and P). These clones were designated Csf1, 


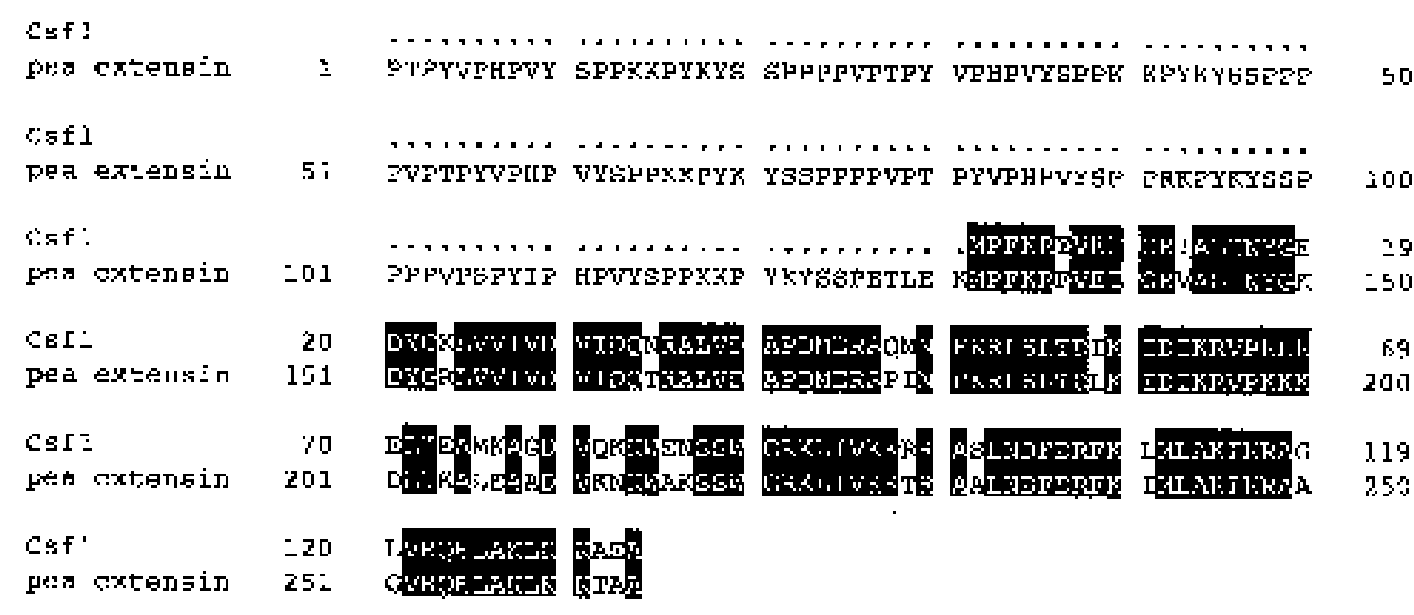

frame of $453 \mathrm{bp}$. Sequence homology was found with $\mathrm{Sn}-2$ of bell pepper (Capsicum annuит L. var. annuum), FB7-4 of tobacco(Nicotianatabacum L.), and gMLP15 of opium poppy (Papaver somniferum L.) at $37 \%, 33 \%$, and $26 \%$, respectively (Fig. 5).

No initiation codon was found in Csf3 cDNA, and it consisted of $998 \mathrm{bp}$ although the length of Csf3 mRNA in the northern blot analysis was $\approx 1,400$ nucleotides. The deduced amino acid sequence for Csf3 showed 68\% iden-

Fig. 4. Alignment of deduced amino acid sequence of Csf1 from 'PMR-142' cucumbers with a homologous sequence, pea extensin. The amino acids are given in single letter code. Identical amino acids in Csf1 and pea extensin are boxed.

Csf2, and Csf3, and the estimated length of the corresponding mRNAs was 800,800 , and 1,400 nucleotides, respectively, based on northern blot analyses with two major ribosomal RNAs as molecular markers.

Ovaries of flowers formed below the 15 th node averaged 22.7 $\pm 0.32 \mathrm{~mm}$ long and $0.68 \pm 0.04 \mathrm{~g}$ fresh weight on the day of anthesis. Pollinated flowers and parthenocarpic unpollinated or NAA-treated flowers showed substantial growth $3 \mathrm{~d}$ after anthesis (Fig. 1B). Parthenocarpic fruit on the higher nodes were larger than others because the ovaries at higher nodes were larger at anthesis (Takeno and Ise, 1992).

The expression of three Csf genes in the naturally parthenocarpic fruit was as high or higher than that in the pollinated fruit (Fig. 1A). The expression of Csf2 in the NAA-treated fruit was almost the same as that in the pollinated fruit, whereas Csf1 and Csf3 were expressed at barely detectable levels in the NAA-treated fruit compared with the pollinated fruit.

Over a 7-d time period, the level of mRNA for Csf2 increased from 2 after pollination (Fig. 2A). An appreciable level of mRNA for Csf1 was detected even on the day of anthesis, and the highest level of mRNA for Csf3 was detected on day 3 after anthesis. During the first $7 \mathrm{~d}$ after anthesis, length and fresh weight of pollinated fruit increased (Fig. 2B).

Expression for all three Csf genes was not restricted to fruit but was undetectable in leaves (Fig. 3). Expression of Csf 2 was not detected in stem tips, but was as high in roots as in fruit, and somewhat less in stem. Expression of $\mathrm{Csf} 3$ was roughly equivalent in roots, stems and stem tips, but it was lower than in fruit.

Nucleotide SEQuences OF CSF cDNAs. The Csf1 cDNA consisted of $756 \mathrm{bp}$ and contained an open reading frame of $399 \mathrm{bp}$. The deduced amino acid sequence for Csf1 showed $75 \%$ identity with an extensin isolated from pea (Pisum sativum L.) (Fig. 4).

The Csf 2 cDNA consisted of 826 bp and contained an open reading tity with about two-thirds of the $\mathrm{C}$-terminal amino acid sequence for a large subunit of $60 \mathrm{~S}$ ribosomal protein L3 isolated from Arabidopsis thaliana (L.) Heynh. (Fig. 6).

\section{Discussion}

We cloned three cDNAs for genes whose expression was induced in fruit of cucumber when growth was triggered by pollination. Among these cDNAs, Csf2 was always expressed when fruit growth was triggered not only by pollination but also by auxin treatment or natural parthenocarpy. The time course of expression of the Csf genes was nearly parallel to that of fruit growth. However, the expression of Csf1 was detected even at anthesis, and the most abundant expression of Csf3 was on day 3 . These results suggest that the role of Csf 2 in the fruit growth is more important than that of Csf1 and Csf3.

Since the three Csf genes were present in fruit of other two cucumber cultivars when growth was induced (data not shown), the Csf genes may be common in this species.

Csf1 and Csf3 were expressed in actively growing tissues and may represent extensin and a fragment of a gene encoding a ribosomal protein, respectively. The genes for extensin and ribo-

Fig. 5. Alignment of the deduced amino acid sequence of Csf2 from 'PMR-142' cucumbers with other homologous sequences, bell pepper CaSn-2, tobacco FB74 , and opium poppy gMLP15. The amino acids are given in single letter code. Identical amino acids in Csf 2 and others are boxed.

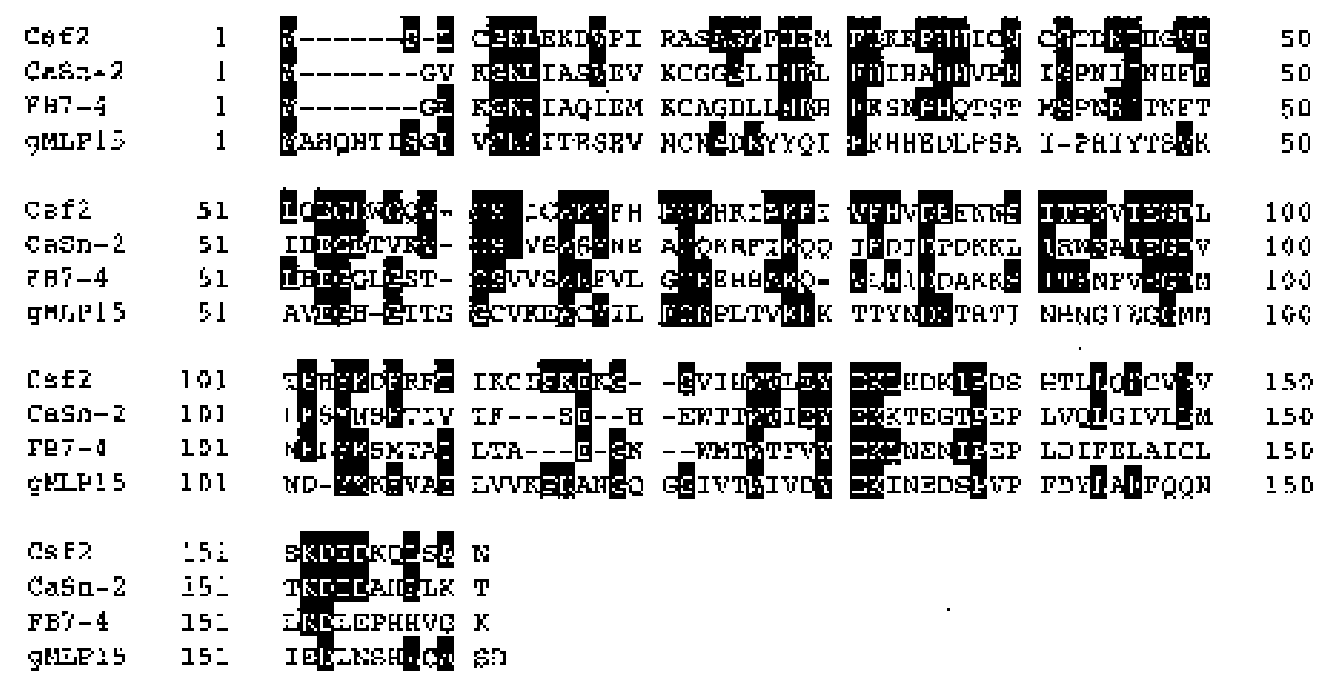




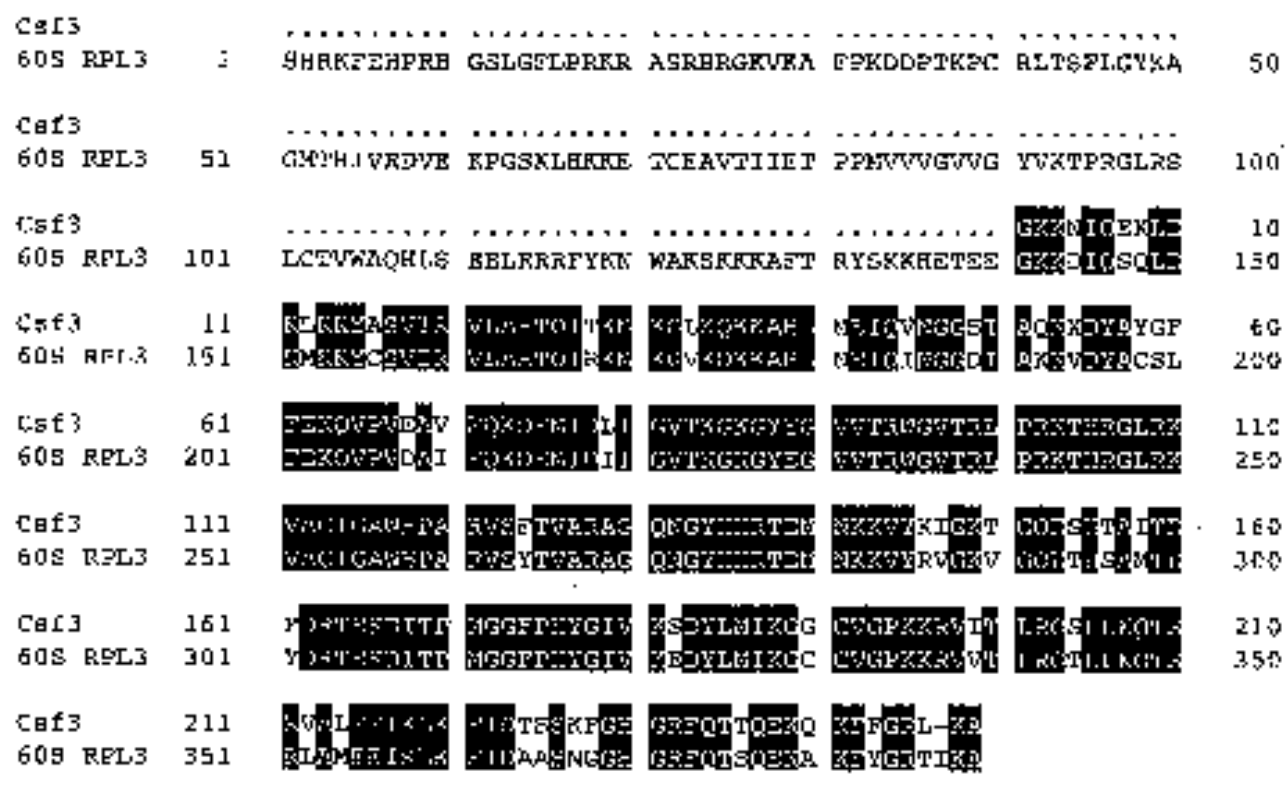

development. British Plant Growth Regulator Group Monogr. 12, p. 211224.

Ledger, S.E. and R.C. Gardner. 1994. Cloning and characterization of five cDNAs for genes differentially expressed during fruit development of kiwifruit (Actinidia deliciosa var. deliciosa). Plant Mol. Biol. 25:877-886.

Lee, T.-H., T. Kato, Y. Kanayama, H. Ohno, K. Takeno, and S. Yamaki. 1997a. The role of indole-3-acetic acid and acid invertase in development of melon $(\mathrm{Cu}$ cumis melo L. cv. Prince) fruit. J. Jpn. Soc. Hort. Sci. 65:723-729.

Lee, T.-H., A. Sugiyama, K. Takeno, H. Ohno, and S. Yamaki. 1997b. Changes in content of indole-3-acetic acid and in activities of sucrose-metabolizing enzymes during fruit growth in eggplant (Solanum melongena L.). J. Plant Physiol. 150:292-296.

Lee, T.-H., A. Sugiyama, J. Ofosu-Anim, K. Takeno, H. Ohno, and S. Yamaki.

Fig. 6. Alignment of the deduced amino acid sequence of Csf3 from 'PMR-142' cucumbers with a homologous sequence, Arabidopsis thaliana $60 \mathrm{~S}$ ribosomal protein (60SRPL3). The amino acids are given in single letter code. Identical amino acids in Csf2 and 60SRPL3 are boxed.

somal protein are expressed in roots and stems of other species, but not in their mature leaves (Marty and Meyer, 1992; Showalter et al., 1992; Stafstrom and Sussex, 1992). The accumulation of mRNAs for extensins and ribosomal proteins is correlated with the growth process. It is possible, therefore, that Csf1 and Csf3 play some role in the regulation of fruit growth in cucumber.

The homology between Csf2 and Sn-2, FB7-4 and gMLP15 is not high, and therefore, Csf2 may encode an unreported protein. The Sn-2 cDNA was cloned from mature fruit of bell pepper (Pozueta-Romero et al., 1995). The FB7-4 gene was expressed during flower formation in tobacco (Neale et al., 1990). However, functions of these genes are unknown. It was reported that gMLP15 was a major latex protein of opium poppy (Nessler et al., 1990). Therefore, the function of Csf 2 cannot be predicted.

We have previously reported that fruit growth of eggplant (Solanum melongena L.) and melon (Cucumis melo L.) is initiated by accumulation of sugars in ovary cells through activation of sugar-metabolizing enzymes (Lee et al., 1997b, 1997c), and these enzymes are activated by auxin (Lee et al., 1997a). Although genes encoding enzyme proteins relating to sugar metabolism may be expressed during fruit growth, the Csf genes isolated from cucumber did not show homology with known genes that relate to sugar metabolism. Characterization of the Csf genes, especially Csf2, may provide new insight into the study of fruit growth regulation.

\section{Literature Cited}

Callahan, A.M., P.H. Morgens, and R.A. Cohen. 1993. Isolation and initial characterization of cDNAs for mRNAs regulated during peach fruit development. J. Amer. Soc. Hort. Sci. 118:531-537.

Dong, Y.H., B.J. Janssen, L.R.F. Bieleski, R.G. Atkinson, B.A.M. Morris, and R.C. Gardner. 1997. Isolating and characterizing genes differentially expressed early in apple fruit development. J. Amer. Soc. Hort. Sci. 122:752-757.

Hampson, I.N., L. Pope, G.J. Cowling, and T.M. Dexter. 1992. Chemical cross linking subtraction (CCLS): A new method for the generation of subtractive hybridization probes. Nucleic Acids Res. 20:2899.

Hedden, P. and G.V. Hoad. 1985. Hormonal regulation of fruit growth and 1997c. Activation of sucrose-metabolizing enzymes and stimulation of sucrose uptake by auxin and sucrose in eggplant (Solanum melongena L.). J. Plant Physiol. 150:297-301.

Marty, I. and Y. Meyer. 1992. cDNA nucleotide sequence and expression of a tobacco cytoplasmic ribosomal protein L2 gene. Nucleic Acids Res. 20:1517-1522.

Mori, H., Y. Takeda-Yoshikawa, I. Hara-Nishimura, and M. Nishimura. 1991. Pumpkin malate synthase. Cloning and sequencing of the DNA and northern blot analysis. Eur. J. Biochem. 197:331-336.

Neale, A.D., J.A. Wahleithner, M. Lund, H.T. Bonnett, A. Kelly, D. Meeks-Wagner, W.J. Peacock, and E.S. Dennis. 1990. Chitinase, $\beta-1,3-$ glucanase, osmotin, and extensin are expressed in tobacco explants during flower formation. Plant Cell 2:673-684.

Nessler, C.L., W.G.W. Kurz, and L.E. Pelcher. 1990. Isolation and analysis of the major latex protein genes of opium poppy. Plant Mol. Biol. 15:951-953.

Pear, J.R., N. Ridge, R. Rasmussen, R.E. Rose, and C.M. Houck. 1989. Isolation and characterization of a fruit-specific cDNA and the corresponding genomic clone from tomato. Plant Mol. Biol. 13:639-651.

Pozueta-Romero, J., M. Klein, G. Houlne, M.-L. Schantz, B. Meyer, and R. Schantz. 1995. Characterization of a family of genes encoding a fruitspecific wound-stimulated protein of bell pepper (Capsicum annuum): Identification of a new family of transposable elements. Plant Mol. Biol. 28:1011-1025.

Salts, Y., R. Wachs, W. Gruissem, and R. Barg. 1991. Sequence coding for a novel proline-rich protein preferentially expressed in young tomato fruit. Plant Mol. Biol. 17:149-150.

Showalter, A.M., A.D. Butt, and S. Kim. 1992. Molecular details of tomato extensin and glycine-rich protein gene expression. Plant Mol. Biol. 19:205-215.

Stafstrom, J.P. and I.M. Sussex. 1992. Expression of a ribosomal protein gene in axillary buds of pea seedlings. Plant Physiol. 100:1494-1502.

Takeno, K. and H. Ise. 1992. Parthenocarpic fruit set and endogenous indole-3-acetic acid content in ovary of Cucumis sativus L. J. Jpn. Soc. Hort. Sci. 60:941-946.

Takeno, K., H. Ise, H. Minowa, and T. Dounowaki. 1992. Fruit growth induced by benzyladenine in Cucumis sativus L.: Influence of benzyladenine on cell division, cell enlargement and indole-3-acetic acid content. J. Jpn. Soc. Hort. Sci. 60:915-920.

Tieman, D.M. and A.K. Handa. 1996. Molecular cloning and characterization of genes expressed during early tomato (Lycopersicon esculentum Mill.) fruit development by mRNA differential display. J. Amer. Soc. Hort. Sci. 121:52-56.

Wang, H., H. Wu, and A.Y. Cheung. 1996. Pollination induces mRNA poly(A) tail-shortening and cell deterioration in flower transmitting tissue. Plant J. 9:715-727. 